\title{
The Improvement of Economical Situation, A Need to Reduce Criminal Situation
}

\section{Erton Kaleshi}

\author{
Economic Faculty, University of Tirana
}

\section{Doi:10.5901/ajis.2015.v4n2p567}

\begin{abstract}
In this paper we will discuss some of the economic factors and their impact on the level of criminality causes that lead to economic crisis, adding unemployment and poverty, and the consequences of this phenomenon, especially in connection with the crime. The purpose of this paper is to assess how the criminal behaviour and the justice system are affected from economic decline that affects the country. The cost of crime estimates can play an important role in helping the government in the fight against crime. The money which is spent from the state budget can be used in the evaluation of crime reduction policies. Important task of the criminal justice system is the reduction of crime and fear of crime as economic and social costs.
\end{abstract}

Keywords: Economy, Crime, economic crisis, cost of crime, criminal politics.

\section{Introduction}

Weighted Economic are often the underlying criminal behaviour. Criminal behaviour except when it caused from personality disorders or from irrational impulses was "convinced" the rules of rationality. Penal commitment authors are more susceptible to the benefits that would bring conducting illegal behaviour, but many of them are afraid from the harsh penalties that apply in the case of performing these behaviours. Economic theory can explain some illegal behaviour by assisting in the design of efficient penal policies that will reduce benefits and reduce costs (G. Becker, Crime and punishment: an economic analysis, in "Journal of political economy", 1968, LXXVI, pg. 169-217). This is the first relations between the economy and crime. A second report covers the real criminal behaviour defined as a "free behaviour" so the active subject is free to make its own estimates between the costs and benefits and finally to decide whether or not to pursue criminal offense. According to criminologists not all criminal behaviour may be called "free". Penal offences that are part of economic crime category in most cases performed by individuals with higher social status, in the context of a legitimate business activity and abusing with others confidence who becomes victims of these behaviours. These are crimes that can be performed by professionals or business executives to increase the benefits of the criminal enterprise or from managers or from employees of this company. All conceptual definitions follow different evolutions of the economic relations between the thresholds of being legal or illegal and have as his criterion the legal norms in a given context of space and time (W. Bonger, Criminality and economic conditions, Bloomington, Ind., 1969).

A third relation between the economy and crime relates to the link between crime and markets. Economy and criminology help us to understand the relationship between the business cycle and crime and give us elements to understand how different crime distorts the markets making in them to flow a large amount of criminal proceeds. When this wealth invested in the legitimate economy legitimizes changing market conditions (products, working conditions, capital) and facilitating the infiltration of criminal economy in the national economy. Many criminological studies have been conducted to see the links between growth and decline economy or criminality. According to these studies, the most serious crimes are easy related and not constant with crime in decline economy period. Generally, in periods of recession, crimes are not notable increase; crimes against property, including violence, in periods of economic downturn intended to grow; minor's crimes tend to increase in periods of economic growth and reduce during the recession ( $F$. Hagan, Introduction to criminology, Nelson Hall, Chicago, 1990pg. 106.). Other studies show that the links between the economy and crime, although the politics implications of macro and micro level, they are contradictory. Also the studies have shown that there is is a connection between economic growth and criminality. The economic growth brings increase forms such as: white collars crime, crimes that affect social policy, crimes committed by employees. In terms of banal crimes, it exists, but realizes a rise in the ranks of the working classes (Hysi, V., Criminology, Kristalina-KH, Tirana, 2010 pg 354.). 


\section{Economic Decline and Its Effects}

During an economic recession the unemployment rate increased within a short time as many factories and production lines unexpectedly shut down. Remittances significantly reduced. Anyone tries to sell what it can from these factories causing a decline in productive activities price. Banks stop lending, while many other loans which issued previously seem indelible. Financial markets incur concussion which is reflected in the decrease prices of shares or other trading securities in these markets leading to a significant number of bankruptcies. Reducing the investment by reducing the economic growth rate, all these will lead to a deterioration of public communication: the politics with the electorate, political factors with each other but also with public media. The effects of the aforementioned attack and create concern in the lives of other society members. This entire situation translates into suspicion and instability in family incomes, in the living standards, in safe future. Considering all these consequences, people will begin to seek alternative to save their level of living or to minimize the possible losses that could have. These alternative solutions can be two types, lawful or unlawful. Among the legitimate alternatives can be mentioned the change of lifestyle by focusing more on life saver and illegal alternatives push individuals toward criminality. Another effect related to the aggravation of the economic situation due to financial crisis has to do with the start of big protests and popular discontent. These moves, that are used largely by destabilizing anarchist elements, will largely deepen such a crisis and beyond the parameters that would be normal in a crisis situation. Modern economic have concludes that the factors that cause the real economic crisis occupy an important place also psychological factors that relate to the humour of the population. Moreover, in an insecurity situation intimidation of entrepreneurs and managerial elites will bring an aggravation and a delay in finding and applying the right solution.

\section{The Meaning of Criminality}

Criminality is defined by the science of sociology as a form of deviant behaviour from acceptable norms and rules of society. A general definition of the crime is based on the premise that the action or acts committed by an individual affect natural rights that are given to the person entitled by birth. To assess criminality need to evaluate many variables, some of which, while having a significant impact on crime are not easily measurable and applicable. Definition of what is the crime often requires the inclusion of a group of solid rules that complicate social interactions. Criminal activity varies extensively, affecting a large number of legal relations: we can mention offenses affecting life, health, property, administration of justice, constitutional order, the regular functioning of public administration, free elections, economy, morality, dignity. For criminologists is very important the measurement and studying the crime, causes and various forms of his appearance (Hysi, V.,Is the criminality really known; reflections and the opportunity for better measure of crime in Albania, in magazine : "Juridical Study" n.1 Faculty of Law, Tirana 2010, pg 274). The science of criminology uses several methods for this purpose which splits into quantitative methods and qualitative methods. While using these methods criminologist should consider two basic principles: objectivity of the study and observance of professional ethics. Collecting data about the causes and status of criminality will help us later for drafting of effective strategies in the fight against crime and especially in prevention of it (Latifi, V., Elezi, I., Hysi, V., Politics combating crime. JURIDICA, Pristine, 2012,pg 13.). According to official statistics, crime in Albania is a growing dominating our society to its foundations. Cases of businessmen murder, known or not, are a strong evidence for the existence of powerful criminal roots that exist in our country. Crime in the family is also a daily phenomenon with a high number of casualties. Statistics last year's show a frightening reality that we live in silence without being able to do something.

\subsection{Economy and Crime}

Many researchers have shed light on the relationship between economic factors and crime. Criminological studies in this area have reached conclusions not very convincingly, the criticized and often contradictory. This debate is about the actual considering the fact that the US is noticed simultaneously two phenomena: economic expansion and reduction of crime rates. Is thought that all of this is a result of social and economic policies who is very effective in this country, which has provided employment opportunities in that part of society that many tended to enter the path of crime. Many criminologists have studied the relation amongst economic conditions and crime. This connection has been studied about 40 years ago by Becker. According to him, individuals divide their time between legal activities and dangerous illegal activities. If the income from legal options is less likely to be insured than the proceeds of crime, then crime will become more frequent. (Kurti, S., Lectures on the subject "Economics and criminality, Faculty of Law, Tirana 2013). Economic 
factors that have the greatest influence on the state of crime are unemployment and poverty. Many studies look at the poverty as the main cause of the crime situation. However nowadays except poverty the most important thing is economic inequality. This is also the opinion of some authors, according to whom the capitalist economic system limits individual choices: individuals from the lower layers of society have a choice more limited than the middle class or the upper echelons of society who are more likely to succeed (Sheplyski, J., Marxist criminologist, published in the magazine: "The sage Dictionary of Criminology", 2001 pg172). Based on this opinion many countries pursue such social politics and economic situation in order to help people with low incomes. Except poverty, another factor weighing in studies carried is unemployment. In observations conducted in many countries has shown that there is a connection between increasing unemployment levels and increasing crime rates. In this way, we made question such as: the unemployment was caused from the crime or was the crime that caused unemployment, or perhaps there is a third factor that causes these two?

Many researchers have been conducted to answer their questions and generally the results are mixed. Studies Engel and Nilsson (2003) are examples of a positive relation between unemployment and crime while Chisholm studies and Chloe (2005) talk about opposite results. Out of 35 studies performed trustworthy in 1987 by Box, 20 of them showed a positive relation between unemployment and crime. Most of the studies shows that during periods where unemployment is on top there is a growing rate of crimes against property and has no effect on violent crime. In addition to the factors analyzed above an important role in the state of crime is inflation along the periods of growth or collapse of the economy. The phenomenon of crime of "white collars" has generally been only developed countries but now, rattling reflects in developing countries and not developed. Many studies have been conducted to see the connection between the decline or growth of the economy and crime. Based on a variety studies completed that exist about the relationship between the economy and crime, the most serious crimes was easier relating and not constant with crime in periods of economic decline. In countries like Switzerland and Norway, with high levels of economic welfare, it is concluded that crime rates are at low levels, thanks to the social politics who take governments of these countries. In conclusion we can say that economic factors and crime are cross with each other and if it does not controlled can lead to serious problems first for the individual and then to the whole economy of a country.

\section{The Impact of Economic Factors in Crime}

Economic crises attract the after effects of society. One of these consequences has to do with crime and delinquency status. Earlier we saw that changing economic conditions have a major impact on the increase or decrease of the crime situation. It is noted that in the family, and especially young couples, where as a result of the economic downturn and disagreements arise, disputes and debates that often degenerate to divorce and domestic violence. In accordance with criminological theories that propose the existence and mechanical link between the rise in property crime and violent crime during periods of economic crisis aided us analysis of international studies in this area (Voices of the vulnerable: The economic crisis from the ground up: http://www.voicesofthevulnerable.net). National analysis regarding the impact of the economic crisis on vulnerable populations has highlighted the potential effects of the economic crisis on crime. The data recorded politics e about crimes of murder, robbery and motor vehicle theft deliberately based on 15 countries of the world; in periods of global financial crisis in 2008/2009 arise some important facts on the matter. So as in periods of economic crisis as well as periods with the economy not in crisis, economic factors play an important role in the development mift of crime trends. Statistical models identify an economic forecast for at least one type of crime in 12 countries, suggesting general assistance between economic change and crime. According to some researchers, while the financial crisis hits vulnerable populations worldwide, leaders of different countries should look for a solution about increasing racial tensions, crime and violent outbreaks in communities. This philosophy is based on the premise of increased crime victims and the fact that the perpetrators of these crimes represent dangerous groups as well come up in times of crisis. If these states would be aimed towards a common solution to this problem would result then needed an accurate international information and important to recognize trends and levels of crime (S. Cameron, The economics of crime and deterrence: a survey of theory and evidence, Kylos, vol.41, n.2, 1988, pg 301). The voices of the victims report that the impact of financial crisis on the growth of crime is very high. Where the financial crisis manifested through the fall or the development of a negative economy and unemployment is high, a large number of individuals suffer severe that also lead to reduction of income. Consequently, this part of the population quick resolution of this problem will find committing illegal acts. Stressful situations are the cause of many violent crimes. Unemployed persons may become increasingly intolerant and aggressive, especially in their families (Economic and Social Council Resolution 2002/13, annex). 
In most cases criminologists to collect data about the state of criminality use the information you provide official statistics of a certain state. Although these data are of great importance to recognize the level of crime in a particular place they cannot forecast the future of the state of criminality. For this reason, researchers evaluate what changes are likely to occur as a result of economic changes. Crime and economic crisis have become commonplace in everyday language, the media and the diplomatic and academic discussions. The link between economic decline and crime can best explain the change of state of criminality during different seasons passing through a country's economy. Seasonal patterns of criminality related to the emergence of various types of illegal behaviour in certain circumstances and during certain time intervals. So, for example some typical types of murders happens more in summer than in winter; some crimes like robbery have their peak holiday seasons. Seasonality is also present in economic time series such as unemployment coefficient change due to various seasonal levels as production in agriculture, fishing, and construction. In some cases, economic factors, seasonal changes can move continuously along with seasonal variations in crime. According to a report by the United Nations Office on Drugs and Crime (UNODC), the crime situation may peak during the economic crisis. (UNODC, Report of the Informal Expert Meeting on the Impact of Economic Crisis on Crime, Vienna International Centre, 1-2 November 2010). This data is undisputable, although there can be a stable relationship between specific crimes and specific economic factors. Such results are consistent with the theory of criminal motivation suggests that economic stress causes an increase in criminal behaviour. Economic decline of the years 2008-2009 marks a significant change in the leading economic indicators, especially unemployment at about $70 \%$ of the affected countries. In these countries also appeared an increase in some types of crimes as violent crimes and those against property. In some cases the increases were significant showing a double increase in any of the countries affected by the economic crisis is not noticed a decrease in crime.( According to the report, during periods of economic stress doubles the level of robberies, murders and thefts of motor vehicles increased. In 8 of the 11 countries who pass the economic crisis clearly observed relationship that exists between economic factors and crime; http://www.imfstatistics.org/imf/)

\section{The Cost of Criminal Activity during Recessions}

Above we analysed the rise of the situation of criminality in cases of economic crisis. That why people are more prone to commit offenses during such periods can explain through analysis of "economic theory of criminal conduct". This theory was formulated by Nobel Prize winner Gary Becker economy, according to which criminals are rational beings who are driven to act on the basis of maximizing their welfare. In other words, any subject who has the right of choice regarding the performance of a wide range of behaviours makes his favourite choice that will bring greater benefits. To implement economic instruments in the study of criminal behaviour, we can use the theory of choice under conditions of uncertainty or otherwise risk theory. For this we consider a simple example: the decision to pay or not the bus ticket. Not to pay the ticket constitutes illegal conduct does best part definition that we do conduct "criminal". Alternative behaviour of this behaviour corresponds to the case when the subject decides to pay the price of the ticket to afford a safe expense. If the subject would prove to travel for free, threatens to pay a fine if the ticket is detected by the controller. For this reason the result of choosing to travel for free is uncertain and depends on the frequency of checks made on the bus. If the subject is rational and risk neutral, his choice will depend on the confrontation of these two alternatives: thus if the cost of travelling for free is less than the cost (safe) the option to pay the ticket, rational subject will make a choice "criminal" by performing illegal behaviour. In the above example is very simple calculation and depends on three numbers: a) the price of the ticket $(X) ; b)$ the amount of the fine to be paid $(Y) ; c)$ the probability to achieve control of the ticket $(Z)$. The cost of choosing not "criminal", the payment of the ticket price is exactly $X$. While the cost is expected from committing illegal behaviour $(K)$ is an average between 0 (if the entity manages to escape controls) and $Y$ (if implemented control). As a result the average consists of two probabilities and just have $K=0 \times(1-Z)+Y \times Z=Y Z$. This reasoning allows us to identify cases in which it is rational to behave as "criminal", and it includes all cases where $Y Z<X$. Thus we can say that based on the principle of rationality, conducting criminal behaviour is in proportionate to the amount of the fine to be paid and the number of checks carried out by the auditors and in proportion to the cost of conduct "criminal", i.e., if the number of controls is small and the amount of the fine is small, while the cost of the ticket is greater than this would favour conducting illegal behaviour. According to this theory founder Gary Becker, some people become "criminal" not because the goals and motivations that push them to act are different from those of other people, but for the fact that the costs and benefits vary material they may have when performing certain actions they take. This conclusion applies not only in the simplest case to pay or not the price of the bus ticket, but in all those cases when a subject is against the alternative to respect or not the law, so to commit tax evasion or to pay taxes; car to drive drunk or not; to bribe a public official or not; to deal with the production or distribution of narcotics or traffic or not; to perform or not a theft or robbery with violence. 
Through this theory we are able to explain why in situations of economic crisis, people are more inclined to commit criminal acts, but the high importance of this theory is that it serves as a guideline for the design of an effective criminal policy in the fight against crime. In other words it is possible to affect in committing criminal behaviour if fighting is achieved through specific policies affected the costs and benefits that are the foundation of these behaviours, so back to the example above, it is possible to be influenced illegal behaviour or by increasing the amount of the fine or by increasing the probability that the ticket evaders caught and fined by creating a situation where it's most convenient ticket payment.

\section{Conclusion}

Economic decline is harmful to all persons, not only for the present but can affect them in the future. The decline in economic welfare reflected in any activity due to the decline in purchasing power or absence of job brings reduction to social and health services. Consequently of these events have particular growth the corruption and the situation of criminality in general. The costs of crime have become an important tool for decision makers about crime and its impact on society they help to make clear judgments about the relative merits of alternative policies and programs that are already involved in making decisions about the distribution of resources for training crime. It is important that the costs and benefits of the initiatives can be measured jointly. The cost of crime evaluations will be used in many different contexts in reducing crime and demand to analyze crime using cost estimates are likely to rise further. The publication of these results is also an important step in identifying the main deficiencies in our knowledge about the impact of crime on society. (D. Anderson, The aggregate burden of crime, in Journal of Law and Economics, vol. 42, n.2, 1999, pg. 611 ). As in all countries and societies application of Law is the main factor to reduce the costs of crime. Implementation and observance of laws need the political willingness of every company in order not to leave the track of corruption and crime in general. Initially this is reached by individual effort and consequently comes increasing the economic prosperity and reducing the cost of crime. We cannot pretend that reduction of crime will have economic growth. In society is not enough to reduce crime, but we must work to mitigate its consequences. Society and the state should try to increase living standards and applying the law.

\section{References}

Anderson, D., The aggregate burden of crime, in Jurnal of Law and Economics, vol. 42, n.2, 1999.

Becker, G., Crime and punishment: an economic analysis, in "Journal of political economy", 1968, LXXVI.

Bonger, W., Criminality and economic conditions, Bloomington, Ind., 1969.

Cameron, S., The economics of crime and deterrence: a survey of theory and evidence, Kylos, vol.41, n.2, 1988.

Hagan, F., Introduction to criminology, Nelson Hall, Cikago, 1990.

Hysi, V., Criminology, Kristalina-KH, Tirana, 2010.

Hysi, V.,Is the criminality really known; reflections and the opportunity for better measure of crime in Albania,in magazine : "StudimeJuridike" n.1 Faculty of Law, Tirana 2010.

Latifi, V., Elezi, I., Hysi, V., Politics combating crime. JURIDICA, Pristina, 2012.

Kurti, S., Lectures on the subject "Economics and criminality, Faculty of Law, Tirana 2013.

Sheplyski, J., Marxist criminologies, publishen in the magazine: "The sage Dictionary of Criminology", 2001.

UNODC, Report of the Informal Expert Meeting on the Impact of Economic Crisis on Crime, Vienna International Centre, 1-2 November 2010 